\title{
Psychotherapy for end times
}

\author{
Robert D. Romanyshyn, PhD.
}

FRANCE

\begin{abstract}
The broken connections between us and nature have left us feeling homeless in a world not only imperiled by multiple ecological crises and their political, economic, medical and social consequences, but also orphaned by the increasing turn to the allures of the digital world with its loss of place and embodied presence. In this context, this essay proposes that psychotherapy can be a place for homecoming in a fractured world. Exploring the key role of the grieving process in homecoming, I draw on my work in Jungian psychology, phenomenology, poetry and storytelling to show that our engaged, embodied presence with nature can re-mind us of the miracles in the mundane, the extraordinary in the ordinary, and can open our hearts to the wonder, mystery, beauty and sacred dimensions of human life.
\end{abstract}

\section{Whakarāpopotonga}

Kua waiho rongo kāinga-korehia mai tātau e ngā here motumotu i waenga i a tātau me tētahi ao kāre nei e whakaraeraehia e te tini taupuhi taiao mōrearea me ngā hua o ā rātau mahi tōrangapū, tikanga ōhanga, hauora, hāpori hoki, engari kua whakapanihia anō hoki e te rahi haeretanga o te mau ki ngā kukumetanga o te ao matihiko koia nei te ngarohanga o tōna wāhi tū me tōna ngarohanga aroaro-ā-tangata. I roto i tēnei horopaki, e kī ana tēnei tuhinga ko te whakaora hinengaro hei wāhi hoki kāinga mai i roto i tētahi ao whawhati. Tūhuruhia ana te kaupapa matua o te hātepe mōteatea rō hokinga kāinga, ka huri au ki āku mahi hinengaro Hungaiana,mātauranga pūtaio whakaharahara, toikupu, me te kōrero paki hei whakaatu ko ō tātau tūnga, aroaro-ā-tangata pānga taiao, mā ēnei tātau e whakamaumahara ake i ngā marutuna i rō mahinga ia rā, te marutuna o te waimemeha, ā, e whakatuwhera ō tātau ngākau ki ngā mea whakaharahara, pirikoko, ātaahua, me te tapu o te koiora tangata.

Key words: end times; grief; ecological crises; unconscious dynamics; homecoming; depth; surface; embodiment.

\section{Introduction}

We live today not only in the shadow of the bomb, but also in the deepening darkness of environmental collapse as the polar icecaps continue to melt, the western arm of the Gulf

Romanyshyn, R.D. (2021). Psychotherapy for end times. Ata: Journal of Psychotherapy Aotearoa New Zealand, 25(1), 11-17, https://doi.org/10.9791/ajpanz.2021.02 


\section{PSYCHOTHERAPY FOR END TIMES}

Stream in the North Atlantic Ocean is weakening, the seas and oceans become increasingly polluted, the buildup of carbon-based greenhouse gases reaches ever higher levels, and raging fires, floods and other weather catastrophes are increasingly destructive, while animal and human habitats are destroyed and the number of homeless refugees swells almost beyond belief. All the bodies of knowledge we create, like the bodies of those who create them, cast a shadow.

Death is now the invisible presence haunting our therapy room, re-minding us that the world as we have known it is ending and not knowing what kind of world might be beginning.

How do we do psychotherapy in such times when the impending sense of an ending darkens our every word, gesture and mood with fears, anxieties, strategies of denial and fantasies of sheltering in old, familiar patterns?

\section{Surface and Depth}

A psychotherapy for end times makes a place for the spirit of the depths that lingers and even haunts the spirit of the times. This distinction, which is basic to Jung's psychology, deepens our understanding of unconscious dynamics. It also recognizes that these dynamics are not only manifestations of psychopathology, but also revelations of the deeper wisdom of the psyche.

\section{Four Levels of Unconscious Dynamics}

Throughout the twentieth century Freud and Jung plumbed the various levels of unconscious dynamics. Beneath the level of personal and familial unconscious dynamics of Freudian psychology, phenomenology explored the cultural-historical levels where gender, race, cultural history and historical events play their part in shaping one's character and one's suffering. In the same period, Jung was uncovering the Collective Archetypal level, where mythic patterns and archetypal themes cradle the individual's life and suffering within the larger stories of humanity. In addition, Jung also described a Psychoid level of unconscious dynamics, where psyche and nature are one, pivoting round each other so that what is, from one angle, a psychological experience, is from another a material event. Jung's work with Wolfgang Pauli was the impetus for this insight, and synchronicity was for Jung a key signature of this kind of occurrence (Jung, 1946/1954).

Such moments do seem extraordinary, and von Franz (1980) has noted that in earlier times they would have been understood as miracles.

But are not such moments even today miracles, moments that do feel miraculous, and is it our incapacity to experience miracles today that marks the measure of our misery? Moreover, might the recognition of the psychoid level of unconscious dynamics be timely when collectively we are witnessing the destructive consequences and indeed even the insanity of continuing to uncouple human suffering from the suffering of nature and its creatures?

If one considers that depth psychology is not only a system of psychotherapy, but also, and perhaps more significantly, a new form of education that keeps soul in mind (Jung, 1946/1954), then each level of unconscious dynamics can be understood as a teaching, a 
lesson about soul making, about living, loving and working with soul in mind. More specifically, this new form of education can be framed as learning how to love and bringing that lesson into one's life and work.

This education into soul making is the complement of a higher education, which my colleague Mary Smail has aptly called lower education. As such, it is not a step-by-step linear process toward progress. Rather, it is a spiraling process in which the image of steps gives way to the image of layers in which each layer contains or preserves what precedes it and transforms it. The process of soul making, therefore, is not about getting ahead. On the contrary, it is an alchemical process of continuous dissolution and coagulation, of letting go or sacrificing old ways of knowing and being and re-forming them as one slowly learns how to see in the light of soul, a darker light than that of the Solar, seemingly enlightened, mind.

If, for the sake of this presentation, we arrange these layers of unconscious dynamics more or less according to the times of their historical appearance, then each layer can be seen as both the many faces of love as they appear and are transformed.

At the personal layer the relationship between oneself and another is the alchemical vessel where all the complexities, power disguises and the inevitable sense of loss and grief that shadow love appear (Goodchild, 2001). Mary Shelley's story of Frankenstein can be read as a psychological primer on love and its shadows. In her story Victor Frankenstein is an emblem of the destructive consequences of love disguised as power while the Monster he creates is a seed of hope for the redemptive possibilities of love (Romanyshyn, 2019).

At the cultural-historical layer the personal layer of love's complexities and shadows is enfolded within the spirit of the times where gender, racial, economic and other roles can act as forces of oppression. But while these roles can serve as forces of oppression, they can also be occasions for the individuation process (Jung,1934/1954). Dante's Divine Comedy can be read as a late medieval poetic description of individuation, and Mary Oliver's evocative poem, The Journey (1986), is a contemporary example.

At the Collective-Archetypal level the lesson of learning how to love rises from the spirit of the depths within which one's story is framed within the larger stories of humanity, where mythic patterns and archetypal themes of the ancestors cradle the individual's life and suffering, a moment which I have often noticed can have a salutary and even therapeutic effect. In these depths love is, as Rilke (1986) notes, the most difficult work of all apart from which everything else we do is but a preparation.

Beyond the human condition, learning how to love at the Psychoid level is learning how to be a good steward to all creation, an agent in service to its appeals.

\section{Psychotherapy as Homecoming}

As a lesson in learning how to love in the face of loss, a psychotherapy for end times becomes a homecoming, a re-turning to re-member the many ways the bonds between the sensual flesh of the embodied mind and the sensuous epiphanies of the natural world have been severed. This broken bond has been the central theme of my work over the years regarding the origins, development and crises of our scientific-technological world view (Romanyshyn, 1989). What I discovered in this work was an underlying mood of sorrow, a shared symptom of soul, a fever as it were of the Anima Mundi, awakening us to how learning how to love in 


\section{PSYCHOTHERAPY FOR END TIMES}

the face of loss is also learning how to grieve, a hard truth that undoes all the strategies of denial that would dismiss the necessity to mourn what has been lost, disregarded, forgotten or otherwise exiled to the margins of the disembodied ego mind. In the context of this broken bond, I began to witness in myself and my patients how psychotherapy as homecoming is a mourning process, which feels so necessary now when "Twentieth century Oedipal man has forgotten his mythical forebears and is haunted by what he has failed to mourn” (Mogenson, 2004, note 31).

Psychotherapy as homecoming uncovers the healing power of the grieving process. So crucial in our time of need when the climate of nature and that of soul are heralding end times.

\section{Patterns of the Grieving Process}

In The Soul in Grief: Love, Death and Transformation (1999) I described a personal account of the healing power of the grieving process. Mired in the depths of loss after the unexpected death of my first wife in 1992, something happened which, in recollection, felt like a miracle. Apart from any plan or even conscious intention I had had, it took place on a Sunday while I was sitting on a bench that looked out on a wide expanse of a green pasture. A late afternoon sun covered the field, which was about a hundred yards away and had a gentle downward slope. A soft breeze stirred the grass. As I sat there in the limbo space of reverie, neither awake nor asleep, suddenly I was wrenched back into the moment by the greenness of the grass rolling toward me, as if the green of the grass had been unloosed by that gentle breeze to become pure colour. Time seemed to fade away as the green colour unbound by form was gathering itself into a series of waves increasing in strength and power as they washed over me. When they began to subside, I heard a sound of winter ice cracking around my frozen heart.

While it would take a long time for the winter of grief to complete itself as the pattern of love, loss, descent and transformation continued, this singular moment was a beginning, a baptism as it were, a blessing. Later, as I explored the grieving process, I found that this pattern lives within the depths of the Collective and Psychoid layers of the conscious mind. Attending to the themes and images in the stories of Orpheus and Eurydice and Psyche and Eros among others, my grieving process was enfolded within those larger stories.

The grieving process not only changed me, it also deepened my practice of psychotherapy.

Every patient who crosses the threshold into the therapy room is a story that resonates at all four layers of the unconscious mind. Embodied and enacted in the daily round, a patient's tale is also embedded within cultural-historical and collective-archetypal images and stories that weave their story into the larger narratives of humanity. Moreover, and, I would emphasize of first importance, the story to be attended today is the one in which our sufferings are part of the sufferings of the natural world re-minding us that as part of nature and not apart from it, we are the agents, as it were, in service to its unfolding. Indeed, dare we say that we are the stuff on which nature's story is made on? Dare we not say that and continue to fall into the insanity of splitting ourselves off from creation?

The art of psychotherapy for end times is to discern at which layer of loss the other who comes to us for help, for comfort, for understanding, needs us to bear witness to their 
suffering. That is a difficult art with its own ethical code of soul that applies to both patient and therapist. It would be unethical to ask of the other more than they could bear. It would also be unethical for a therapist to take a patient to layers that he or she has not experienced.

\section{Departure and Return}

In the last stanza of the eighth elegy of the Duino Elegies, Rilke (1939) presents the image of a man who turns and stops and lingers as he stands on a hill looking at the valley of his home. In this image there is a mood of lament that marks the tone of an elegy, and in this melancholic mood the poet wonders about who has turned us in this way so that, he adds, we live our lives as if we are always on the verge of departure.

Once, at some distant point in the past, we did take our leave from the natural world, a world, however, which even as we have left it has not left us, lingering and even haunting soul with images and myths of the garden, of paradise, of home and homecoming.

Technology has been the means of extending our departure from the world of nature to Earth itself, and yet it has been as well the opportunity to consider it as a homecoming. That possibility occurred on 24 December 1968 when the astronaut Bill Anders snapped a photograph of Earth rising above the moon's surface into the black night of space. For the first time in human history, we had an image of our myths of Eden as we looked at the lonely beauty of Earth as our home. Recalling Rilke's poetic image above, we could add to it these questions:

- Is Earth as seen from space an image of our farewell?

- Is Earth as seen from space an image of our homecoming?

- Or is it the painful realization homecoming requires departure?

Before I end my presentation on psychotherapy for end times with an example of each moment, I would add that those three questions mark the threshold of the therapy room where every new beginning is also an ending.

\section{Taking leave}

It was a dark winter day when I made a visit to the local zoo. On this occasion I was going to see the gorillas. Standing in front of the cage of a large, silver-back male, I keenly felt the presence of the bars between us. The gorilla was sitting in the front corner of his cage, and I could see him only in profile. On occasion, however (as gorillas will do with visitors), he would turn his head for a quick glance in my direction. His deeply set, dark, black eyes seemed like pools of time, and in those few brief moments of exchange I felt dizzy, as if I could swim through his eyes into another world. But the gorilla would just as quickly look away, and the spell would be broken.

The cage was so small, especially for so large an animal, and I wondered how he could bear it. His lethargy was inescapable and I thought of the many hours of boredom he must daily endure, wondering, too, if I was reading my own sense of melancholy through him. But I had also been with animals in the wild, and the difference in behaviour, in gesture, and in 
that space between us was pronounced. Caught up in these reveries I had absentmindedly withdrawn an orange from my pocket and was tossing it in the air. The gorilla turned and began to watch me. Without thinking, I tossed the orange through the bars, momentarily oblivious to the prohibition against feeding the animals. The toss of the orange through the bars covered a distance of only a few feet in measured space and took perhaps only a second in clock time. But the gesture and what unexpectedly followed went beyond the normal boundaries of space and time. One would have expected the gorilla to take the orange and retreat to the far corner of the cage to eat it. But this gorilla did not do that. Instead, he tossed the orange through the bars back to me, I caught it, and in my astonishment, I tossed it to him again. We continued like this for perhaps three exchanges, until this ribbon between us, this gesture of play, was broken by the sound of a voice from the far end of the corridor. "Don't feed the animals!" When I turned toward the voice, the gorilla turned away. He retreated to the far end of the cage. He kept the orange.

I left the zoo and walked out into the city. The cold, dark, winter afternoon did little to cheer my sadness. Having left the gorilla inside, I realised the other meaning of my sorrow: I had left the gorilla inside me, inside the cage we have made to keep the wilds of nature apart from us. I was different, changed by that encounter, and even more lonely in the midst of the crowded city. The gorilla had suspended his appetite for a moment. For the sake of an encounter, he had with his gesture bridged an immense gap between our worlds. In that gesture of tossing the orange back to me, he had reached out his hand across an emptiness so vast as to be beyond measure. Together we had built a tremulous bridge of gestures. And, for a brief time, we stood on opposite sides of that bridge, connected in a way that seemed to acknowledge in each other some lost kinship.

On that cold winter day the loneliness of the caged gorilla mirrored my grief at being so far away from home.

\section{Coming Home}

In 2009 I made a short DVD film of a journey I took to the Antarctic, Inner Journeys in the Outer World. Amidst the splendid beauty of those crystal cathedrals of ice, in that place so far from home I felt as if I was on the way home. The DVD can be viewed on the home page of my website: Robert Romanyshyn.com.

\section{References}

Goodchild, V. (2001). Eros and chaos: The sacred mysteries and dark shadows of love. NicolasHayes, Inc.

Jung, C. G. (1934/1954). The Development of Personality. In C.G. Jung, The Development of

Personality: The Collected Works of C.G. Jung (R.F.C. Hull, trans.), vol. 17. Princeton University

Press.

Jung, C. G. (1946/1954). Analytical Psychology and Education. In C.G. Jung, The Development of Personality: The Collected Works of C.G. Jung (R.F.C. Hull, trans.), vol. 17. Princeton University Press. 
Mogenson, G. (2004). The afterlife of the image. Spring 71, 89-112.

Oliver. M. (1986). The Journey, in Dream Work. The Atlantic Monthly Press.

Rilke, R. M. (1939). Duino Elegies (J.B. Leishman and Stephen Spender, trans.).W.W. Norton.

Rilke, R. M. (1986). Letters to a young poet (Stephen Mitchell, trans.). Vintage.

Romanyshyn, R. D. (1989). Technology as symptom and dream. Routledge.

Romanyshyn, R. D. (1999). The soul in grief: Love, death and transformation. North Atlantic Press.

Romanyshyn, R. D. (2019). Victor Frankenstein, the Monster and the shadows of technology: The

Frankenstein prophecies. Routledge.

von Franz, M. L. (1980). Projection and re-collection in Jungian psychology: Reflections of the soul.

William H. Kennedy (trans). Open Court.

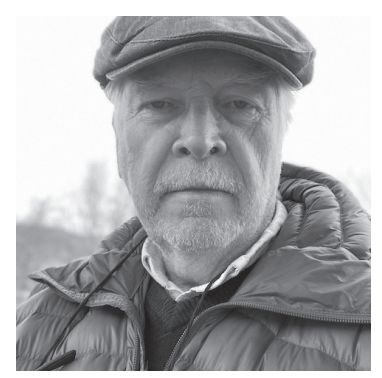

Robert D. Romanyshyn is an Affiliate Member of The InterRegional Society of Jungian Analysts. He has published eight books including Victor Frankenstein, the Monster and the Shadows of Technology: The Frankenstein Prophecies, Leaning Toward the Poet: Eavesdropping on the Poetry of Everyday Life, The Wounded Researcher, Ways of the Heart, The Soul in Grief: Love, Death, and Transformation, and Technology as Symptom and Dream. He has also published poems, numerous articles in psychology, philosophy, education and literary journals, written a one act play about Frankenstein, and in 2009 he created a multimedia DVD entitled Antarctica: Inner journeys in the Outer World. He is a Professor Emeritus of Clinical Psychology at Pacifica Graduate Institute and now lives in the Aude region of southwest France with his wife Veronica Goodchild. 